\title{
Starting from the Heart \\ -Some Thoughts on Ways to Promote Teachers' Intrinsic Professional Happiness
}

Zheng Saifen, Zhou Chuner

Hangzhou Normal University

\begin{abstract}
Teachers are engineers of human soul and they are supposed to be a happy occupation. But in fact, the occupational stress becomes greater and greater, the burnout becomes more serious and teachers' happiness is losing. Promoting teachers' professional happiness is not only good for the development of teachers themselves and for the growth of students, but also for the good development of education. So, it is a hot topic to talk about how to promote teachers' professional happiness. From the heart, which means that make the teachers' professional happiness deeper and longer from the intrinsic origin. Building the proper professional ideology, right values and healthy lifestyles, which are good for teachers to know the occupation and relieve the stress, is an important way to promote teachers' intrinsic professional happiness.
\end{abstract}

Keywords: teachers, professional happiness, intrinsic origin, promoting ways

Published Date: January 2018

Published Online: $31^{\text {st }}$ January 2018

Corresponding Author: Zhou Chuner, Hangzhou normal university hzzce@126.com

\section{Introduction}

Ye Lan said that there was no high-quality education without promoting teachers' life quality, there was no students' spiritual liberation without teachers' spiritual liberation, there was no students' active development without teachers' active development, even there was no students' creative spirit without teachers' educational creation. ${ }^{[1]}$ So whether the teacher is happy or not, not only have an effect on students' growth in personality, but also decide the development of the education. It is a hot topic to talk about the promotion of teachers' professional happiness.

\section{Concept and content}

Teachers' professional happiness is a kind of teachers' lasting happy experience in their own professional growth and development. In the teaching process, teachers use education intelligence to make education innovation, which can help them get the active evaluation from students and society and feel the intrinsic pride and happiness. More and more people realize that the professional happiness is the important situation for the education and the intrinsic dynamics for the professional development. But now the losing of teachers' professional happiness becomes a fact that contains much helplessness and powerlessness.

Teachers are supposed to live in a poetic spirit world and work skillfully in professional growth. A teacher means help others get happiness and get selfhappiness as well. Obviously, it is urgent to promote teachers' happiness. Meanwhile, there are also some external factors, such as the low salary and the incomplete education system. But all these problems need solving by the national social policy. But for teachers, everyone is a unique person who has his own unique physical situation and personality. It is difficult for a teacher to change the physical situation, but it is much deeper and longer to promote teachers' happiness from the intrinsic origin. Well, how to change teachers' inner world in order to promote teachers' happiness? Here are three ways: 


\section{Build proper professional ideology and change from "livelihood" to "lifestyle"}

At present, many teachers have the occupation as their livelihood. It is difficult to find out the balance between pains and gains. Because people are always looking forward to the endless material, but the constant salary can't fit the overloaded working hours, which make all the teachers feel anxious and impatient. Only take the teacher as a livelihood and neglect or ignore their own interests and development, which will take all kinds of disadvantages.

First, cut the relationship between the goal and means. Teachers always use their own happiness (the goal) to get students' high marks (means). On the way to happiness, teachers always think they can't deserve happiness, and some even think happiness is limited, if they get, their student will get nothing. But just candle ideas of "great sacrifice" and "burn yourself out to give light to others" may make professional happiness lose its own source. Second, have the teacher work only as a worker. A worker's labor process means maser the fixed operation and produce the accepted product. So if a teacher only thinks his work is to output the single and replicate knowledge without the creative and investigative teaching process, he will ignore each of his students. How to feel happy if one loses his passion and creativity? It is not a true attitude to ignore and deny the economic function of an occupation, but if we only see the economic function, we will erase the meaning of life. There are many rich men living without rich spirit. They always spend plenty of money getting instant happiness, but how can they save their spirit in the long life? So it is good for teachers to consider happiness by building proper professional ideology. And how to build right values? First, understand the occupational self-values. Every teacher should understand that a teacher himself doesn't have too much wealth in material. When they first chose this job, they thought about the safety and summer and winter holidays with salary to a large extent. The spiritual and material enjoyments are both the wealth. The teacher is a job to cultivate people. Its nature points to people's inner world, so the spiritual enjoyment is much further than the material gains. According to Maslow's hierarchy of needs, the highest level of people is the self-fulfilling, and then the selftranscendence. And the occupation is the best carrier. Understanding the occupational values can help teachers treat gain and loss properly, put the psychology in a correct place and relieve the occupational stress.

Second, get the occupational self-identity. From the heart, be sure of the industry's values and identity of teachers, and take the teacher as a "lifestyle ". The change of occupational value identity means build a free and meaningful relationship between a teacher and an occupation. Teachers can live a happy life. The "lifestyle" educational values not only require the outer pride, such as the more material and the higher position(Of course, certain material is the basic in people's life), but also call teachers' true feeling in the heart and work with passion. If a teacher has his personal charm which can attract students, make students learn some knowledge and experience the truth about life and the philosophy of life, he must be a person who loves education, is full of desire and passion ${ }^{[3]}$.

Third, change the occupational self-attitude. Establish a "Love your own job" principle. When teachers change the attitude to their work, they will learn to re-think, learn to learn and find out problems creatively with active exploration in their duplicate work, then they will educate creative students with pioneering and creative spirit who are able to adapt to social progress and change. When teachers change the attitude to their work, teachers will take their job as the occupation, not only a job, but also a job of paying more attention to students' growth and progress and learning how to give. As a teacher, they should have a heart of love for education, get happiness from giving which is the highest level ${ }^{[4]}$. Just like J. Dewey said, as for teachers, "Education is always our own remuneration".

3 Build right values and change from "joyful lifestyle " to " happy life" 
Happiness is a kind of individual subjective experience which is got from meeting needs, using talents and improving power. It is also a kind of lasting and happy experience. It is different from "joy". It is lasting. However, "joy" is a kind of short excitement. Therefore, teachers can't confuse "happiness" because of the importance of "joy". Everyone does everything to get happiness.

Life shows a person is present in the world. It has a closed relationship between existing in the past and in the future. But lifestyle is only a feeling in life and it is at present. Therefore, there are differences between the pursuit of life and the pursuit of lifestyle: In lifestyle, the pursuit is an easy and joyful feeling, such as sweet words and wealth. But in life, the pursuit is an endless existence of happiness, such as family, friendship, love. From "Tension principle of life and lifestyle", lifestyle pursues short joy and life pursues endless happiness. We can't only look for the joyful lifestyle with giving or even breaking the happy life. Building right values and changing from "joyful lifestyle" to "happy life" can help teachers understand happiness in a new way. But how to build right values?

First, experience happiness from the knowledge education. Mencius said, "Men have three happy things: First, parents and brothers are alive. Second, look up and feel no regret to the sky. Look down and feel no regret to the others. Third, teach excellent students." As a teacher, the happiest thing is to educate talents who is suitable and useful for the society with a healthy mental state. In the process of students' growth and progress, teachers experience the happiness of educating people. Educating people is a way of expressing proficiency of teachers themselves and students, releasing personal freedom and getting the most happiness ${ }^{[5]}$.

Second, experience happiness from the life education. The ideal of education has a meaning to face life, take care of life, help life and enlarge life. It also has a promoted value which leads life to be an outstanding and perfect one. Teachers with the ideal experience a kind of happiness that their students are around them and improve the self-life quality and happiness ${ }^{[6]}$. Education is lifelong and it exists in life. Compared with other jobs, education is an enjoy-life process with teachers' care to their students and students' learning. Teachers are play a very important role in students' life. They give love during teaching. In the process of life education, teachers teach their students to pursue the endless life happiness. Meanwhile, they can also feel the meaning of life. The origin of education is life itself, and to wake up life and build life meaning ${ }^{[7]}$.

Third, experience happiness from the professional development. People's happy power is the spiritual pursuit and the needs of inner development. As for teachers, shaping and improving self-quality is the necessary way to get the professional happiness. Pursuing life happiness means teachers improve their own competence, learn and think positively by themselves, explore the meaning of education and learn the life-long learning to achieve their own life goal and make their dreams come true. The goal of life is to respect the life value rather than position and wealth. So find out one's own real mission and explore the potentiality, then put them into life to feel happiness ${ }^{[8]}$.

\section{Build healthy lifestyles and change from "stress" to "positive health"}

According to the survey, teachers' psychological problems becomes more and more serious. Almost $60 \%$ of them think trouble in their work is more than happiness and $70 \%$ sometimes get angry easily. Teachers are in poor health and the incidence of occupational disease is high. Every year, the incidence of teachers' disease is up to $70 \%$ in the physical examination. Men teachers over 45 years old with hypertension and heart disease take a part of $60 \%$. Women teachers with gynecological diseases take a part of $70 \%$. Teachers with oral cavity and throat diseases take the first place more than $70 \%$. Women teachers with intestinal diseases take a part of $30 \%$. And teachers with cervical vertebra and lumbar vertebra diseases take the first place more than $20 \%{ }^{[9]}$.

B. Russell indicated that the root of all misfortune is partly from the social system, and partly from the individual psychology. Emerson said that as for different minds, one world may be a heaven or a hell. 
Whether a man is happy or not, it depends on if he has the ability to feel or get happiness to a great extent. Building healthy lifestyles is good for teachers to get happiness again. But how to build healthy lifestyles?

First, have the positive psychological quality and alleviate teachers' negative emotions. The research Meng Wanjin with his project group did shows that teachers have 21 kinds of positive psychological quality. It is divided into the following six subscales: Wisdom and knowledge, courage, benevolence, justice, temperance and beyond. The best development is thanksgiving, social intelligence and honesty. The worse development is humor, kindness and insight ${ }^{[10]}$. Teachers need wide interests and noble aesthetic sentiment. They also need to learn to reduce tension in their busy life and relax themselves. If they have a positive attitude and an unflinching will, they can build confidence to experience happiness. If they are tolerant, humorous, prudent and honesty, they can make a harmonious relationship among their leaders and colleagues, students and students' parents, which make teachers feel happy indirectly. Teachers have healthy interests and a colorful life out of school, then they use the positive power into class. If teachers have positive psychological quality, they can make selfregulation and release their self-emotions to relieve stress.

Second, build the right goal orientation which is good for teachers' professional growth. The research shows that the mastered goal orientation helps produce problem-focused coping strategies of plans, insistence and self-management, which can promote the formation of teachers' sense of happiness. But the avoid-failure goal orientation helps produce emotion-focused coping strategies of refusing and self-limitation, which can cause the formation of teachers' sense of job burnout ${ }^{[11]}$. We should build our attitude positively, treat gains and loss correctly, and make self-goals properly. Every goal has its own meaning, not the result. When teachers have the same goals as meanings, they will pursue their students' growth and promote their own professional growth. At last, they will get the professional happiness.
Third, keep a healthy lifestyle which is good for teachers' development of body and mind. Health is an important feature of life resources and quality. It is always humans' life goal and it takes most parts of happiness. It also has a deep effect on the happiness index and people's happiness ${ }^{[12]}$. In teachers' spare time, they should pay more attention to their health: Open the windows to get more fresh air and keep the room clean and tidy. Eat more fruits and vegetables to get nutrition and enhance the body immunity. Drink tea which has tea polyphenols to prevent Cancer. Drink chrysanthemum medlar tea to protect eyes. Create a good atmosphere in the office, for example, plant green plants to get physical and mental pleasure. People need to work and they also need to relax. After work, teachers need more exercise. Take more neck exercises to prevent cervical spondylosis. Teachers should have their own time to find out some joy and spiritual sustenance in their work, make some happy elements by changing the ways of work themselves. They should balance work and life with a positive attitude and a fulfilling spiritual world.

\section{Conclusion}

Philosopher Feng Youlan thought that "Realm of Life " could be divided into four levels from low to high: "Nature Realm"(the nature), "Utilitarian Realm"(the practical interests), "Moral Realm"(the justice) and "Universe Realm"(beyond the common matters) [13], which is the same as Maslow's hierarchy of needs. Realm of teachers' life is not only related to their own lifestyles and quality of life in the professional career, but also related to the quality of education and students' growth. Teachers in "moral realm" can be conscious of their own duties and responsibilities, and they are also willing to contribute to their students with consciousness and initiative. They take education as their stage to realize dreams and pursue the "universe realm" constantly. How to understand happiness? Happiness is a kind of mental experience which gets a balance between subject and object without oneself in it. To achieve this state, the key depends on awareness of subject itself. Although some outer objective elements, such as, 
education reforms, economic treatments and schools' mismanagement, have a great effect on teachers who may get job burnout, teachers can still work from the heart, take education as occupation, change their attitude and take responsibility for their own choice. A kind of work with "Though unachievable, aspiration to it remains. "work. A kind of peace with "Look at the clouds changing, see the flowers blooming and falling." Happiness starts with "heart". "Happiness just can be approached, but can't be achieved completely, but pursuing it can make life more wonderful" [14].

\section{References}

[1] Ye Lan, etc.. New Exploration of Teachers' role and development[M]. Beijing: Educational Science Publishing House, 2001.

[2] Wang Fuping. Experience Loss: Inner obstacle of teachers' professional happiness obtained [J]. Teaching Management, 2010(5):20-21.

[3] Lin Dan. Behind Teachers' Professional Happiness- Exploration on Teachers' Professional View: "Lifestyle" or "Means" [J]. Exploring Education Development, 2007(12).

[4] Chen Genfa, Wu Renjie. Discussion on Happiness[M]. Shanghai: Shanghai People's Publishing House, 1988: 113.

[5] Erich Fromm. Man for Himself [M]. Sun YiyiWu Translation. Shanghai: Life-Reading.New Knowledge Bookshop, 1998: 45. 248-250.
[6] Feng Jianjun. Education Happiness: Important Dimensions of Teachers' Professional Development[J]. People's Education, 2008(6): 23-26. [7] Feng Jianjun. Discussion on Life Position of Pedagogy [J]. Educational Research, 2006 (3) : 3032.

[8] [America] Tal Ben-Shahar. Wang Bing, Liu Junjie Translation. Ways of Happiness[M]. Beijing: Citic Press Corp.,2013.

[9] Zhang Daoli, Hua Jie, Li Xiaoyan. Loss and Reconstruction of Teachers' Professional Happiness [J]. Heilongjiang Researches on Higher Education, 2010(12): 108-111.

[10] Zhang Chong, Yu Pengnian."Famous Teachers Project " Paves a Happy Road for Teachers' Professional Development [J]. China Morality, 2011(5):45-47.

[11] Parker P D, et al. Teachers'workplace wellbeing: Exploring a process model of goal orientation, coping behavior, engagement, and burnout[J]. Teaching and Teacher Education, 2012, 28(4): 503513.

[12] Gao Yanchun. Dimension of Happiness of Harmonious Society [J]. Journal of Yan'an University: Social Science Edition, 2006 (6) : 33-35.

[13] Feng Youlan. A Short History of Chinese Philosophy[M]. Beijing: Peking University Press, 1996. [14] Jiang Chang, Zhou Hongyan. Happiness and Elegance[M]. Beijing: People's Publishing House, 2006: 74-75. 